The College awards its own diploma on a two-year course, but an extension of this period to one of three years is envisaged to accommodate adequately the increased practical and theoretical instruction made necessary by recent advances in such techniques as leather dyeing, tanning with synthetic materials, drying and so forth. Moreover, in response to the Ministry's expressed intentions with regard to national colleges, the status of the diploma course is to be raised in respect to the level of the training it provides. Although the diploma is a qualification recognized throughout the world in leather-producing circles, it does not possess the standing of a degree, and therefore the outcome of the protracted discussions on higher awards for technology is, as in all similar colleges, awaited with some impatience.

The College offers its own associateship, which may be awarded after a year's research subsequent to the diploma, or to a graduate of a recognized university after a similar period of study. The provision of now research facilities is the most notable innovation under the extension scheme, and it is worth remarking that all the stages of a research programme, from the bench through pilot-plant scale production to what is almost full-scale production, is here housed under one roof. It is therefore proposed to encourage this aspect of the College's activities more vigorously than in the past, and to seek the co-operation of tanners and chemical manufacturers in the matter. Co-operation already exists between the College and the research associations, and the Leather Department in the University of Leeds, so that in this connexion also the Ministry's recommendations are being implemented.

Outside the diploma course, as much flexibility as possible is permitted, notably in the provision of short courses of three or six months duration on specialized aspects of the subject, and, within the confines of space and staff available, every effort is made to accept students individually for courses of even shorter duration. Short refresher courses of from four to six weeks have been a feature since 1951 , and these are to be extended, especially in relation to the ancillary sciences. Entirely new courses on works and management study in the leather trade are planned, as part of the normal diploma course, in addition to being offered to the industry as a whole.

The College druws its students from all over the world, and although a quota is placed on entrants from outside the United Kingdom, the fact is evidence of the wide reputation it has gained since its foundation. There is a generous staff-student ratio, and with the space now available, and the promise of adequate support from the trade, it is anticipated that the College will play an increasingly important part in the industry to which it belongs.

\section{FIRST NATIONAL CROP PROTECTION CONFERENCE}

$T$

HE first National Crop Protection Conference, sponsored by the Pesticidcs Group of the Society of Chemical Industry and organized in collaboration with the Ministry of Agriculture, Fisheries and Food, the Association of British Insecticide Manufacturers, the British Agricultural Contractors Association, the National Association of Corn and Agricultural Mer- chants, and the National Farmers Union, was held in the Winter Gardens, Eastbourne, during October 31November 3. The theme of the Conference was: "Practical Aspects of the Use of Insecticides and Fungicides in Agriculture and Horticulture". The delegates assembled on the evening of October 31 for the chairman's reception at the Grand Hotel, Eastbourne, and later attended a film show, at which were shown "Management for Milk" (Plant Protection), "Fruit Tree Red Spider" (Shell) "Cabbage Root Fly" (Shell) and "The Rival World" (Shell). The last, a dramatic film illustrating man's ceaseless battle not only for food but also for health and very survival against the insect world, underlined the theme of the Conference during the following days. The Conference proper commenced on the following day, when a short account was given by the chairman, Mr. J. M. Leonard, of the Society of Chemical Industry, of the formation of the Pesticides Group and of the events leading up to the holding of the present meeting. Starting with the formation of the Agricultural Group of the Society in 1942, which gave birth to the Pesticides Panel in 1950, he told how the Panel had itself become a group by 1954, capable of sponsoring the Conference by 1955, which was no mean achievement.

The opening address to the Conference was given by Sir Thomas Dugdale, who touched upon the world's loss of produce to pests, both in the field and in storage. These are serious enough in highly developed countries, but in the less-developed ones they must be very much more serious. Since 1940 there have been enormous strides made in the science -and art-of dealing with crop pests; but looking back he saw many landmarks in crop protection and wondered if there might be such a thing as a "fifteenyear rule" in these developments. Before 1940, the start of the present cycle, tar-oil winter wash for fruit trees was introduced about 1925. Derris arrived in 1910. Lime-sulphur and grease banding was brought in about 1895. Still earlier, in 1880, there are records of 'London "purple' (an arsenical) being exported to the United States. Before the Second World War, links between the manufacturers and the 'official' research stations were slender and few, and differences many, leading to bewilderment on the part of the farmer; now Sir Thomas sees a much healthier state of interaction from which the farmer is not excluded; the Ministry of Agriculture's Approval Scheme has also marked a great advance. $\mathrm{He}$ defined four main groups of pesticides : insecticides and acaricides ; fungicides ; nematicides ; and herbicides. Substances for the control of birds and rodents-mostly the latter--may perhaps be considered as a fifth group. The important points to be remembered are that the use of pesticides must be governed by economics, and that chemicals must not be used as substitutes for good farming. Turning to the future, Sir Thomas asked what scientists have in store for us. Would the fifteen-year rule hold good ? Will systematic fungicides really abolish plant disease? Would the only red spiders left be those in museums ? Or would Nature fill the vacuum she abhorred? There are already a number of pests which have increased in importance due to the elimination of predators by pesticides; one answer to this is the use of more selective insecticides and methods of application. Flies resistant to the chlorinated hydrocarbon types of insecticide are already a challenge in many places. So long, however, as the problems are attacked bearing in mind these 
consequences of large-scale interference with Nature, nothing but good can come of the scientists' work.

The first three papers at the Conference were on general subjects. In a general survey of eelworm problems, Dr. B. G. Peters dealt in broad terms with these insidious pests, which are often not detected until extensive damage has been caused. A general survey of soil pests affecting vegetable crops, by Mr. J. W. Wright, was the subject of the following paper, and a general survey on foliage diseases in arable crops, by Dr. H. E. Croxall, rounded off these introductory talks. Later papers dealt with more specialized aspects. In considering the economics of potato blight control, Mr. H. I. Kingston dealt with the search for substitutes to replace the now very expensive copper compounds, and it appears that small quantities of phenyl mercuric chloride can act as synergists and effect reductions in the use of copper up to 40 per cent. In a paper on virus problems in sugar beet, Dr. R. Hull told how loss due to this disease has been reduced in recent years, thanks to careful rogueing on steckling beds and liberal use of insecticides, especially the systemics. The last two papers of the day, control of pests in arable crops, by Mr. J. L. Hunt, and control of pests in Brassica seed crops, by Mr. S. G. Jary, drew much discussion on matters ranging from the forecasting of pest incidence to the amount of loss which can be suffered by seed brassicas without reduction of eventual yjeld.

The morning of November 2 was devoted to a series of papers on application problems and hazards. The application of materials to control pests and diseases of pea crops was dealt with by Mr. R. W. Shorrock and provoked a lively discussion, in which many references were made to the increasing recog. nition of eelworm as a widespread pest of this crop. The next paper, by Mr. F. W. Morris, on the advantages of high-versus low-volume spraying, was another which led to considerable controversy. Mr. Cameron Gifford, speaking on application aspects of aphis control in sugar beet, brassicas and related crops, emphasized the case for dusting in certain instances. Hazards were dealt with by Dr. E. F. Edson and Dr. J. M. Barnes for application and residue problems, respectively, in a pair of most interesting papers in which emphasis was laid upon the desirability of education for safety rather than 'blanket' legislation. The meeting then passed to consideration of seed dressings. Recent developments in the use and application of dual-purpose seed dressings - that is, of insecticide and fungicide seed dressings - was the subject of a review by Dr. D. Price Jones, and Mr. A. J. Pearson, in a paper on 'Dieldrin' seed dressings, described trials of this comparatively new insecticide against insect pests of the seed and seedling. Taint was discussed by Dr. M. Cohen, who described not only the cases of taint, in which benzene hexachloride is still the principal offender, but also the form of tests used for estimation of off-flavours. Dr. R. de B. Ashworth then gave an account of groups of new chemicals recently included in the crop-protection products approvals scheme.

The last day of the Conference opened with a consideration of glass-house problems. The first paper, by Dr. E. Taylor, dealt with the control of fungi under glass, and was followed by one on control of insects under glass, read by Mr. W. H. Read. The glass-house crops can be more efficiently dealt with bv fumigation and aerosol methods than those out of doors, but, on the other hand, their concentration within small spaces raises a number of its own problems. The remainder of the day was occupied with horticultural problems. Mr. J. E. Garnham, speaking on control of red spider on fruit, described the use of chlorbenzide against this serious pest, emphasizing the importance of its application early against winter eggs and immature mites, and condemned the use of the term 'ovicide' when applied to such a widely active compound. In considering the control of fruit pests other than red spider, Mr. E. L. Williams directed attention to the increasing use of insecticide sprays for pests against which winter washing used to be the standard treatment. In the ensuing discussion many suggestions were put forward for reducing the number of separate spraying operations by mixed applications of insecticides and fungicides. New techniques for the control of pests on hops were described by Mr. Emery, who showed some very spectacular slides on the effect of the insecticide dimefox applied to the soil beneath the bines. In reply to questions, he mentioned experiments showing first that the quantity of dimefox present in the hops on harvest is negligible, and secondly, that any which is present would certainly be destroyed in the process of brewing. Mr. E. J. Hainsworth then read a paper on recent advances in scab control, from which it appears that the growing use of captan and the organo-mercurials calls for discretion and that there is still a case to be made out for the use of sulphur. The final paper, on other aspects of the control of fungus diseases on fruit, by Mr. R. W. Marsh, stressed the inability of the newer scab-controlling insecticides to keep down the mildews which are at present controlled by means of sulphur sprays. $\mathrm{He}_{e}$ also spoke of experiments using phenyl mercuric chloride against apple tree canker.

\section{IONIZING RADIATION AND THE CELL}

A

SERIES of fourteen papers and an introduction by G. Pollard, which were presented at a conference of the New York Academy of Sciences on "Ionizing Radiation and the Cell", have now been collected as a separate issue of the Academy's Annals (59, Art. 3, 467-664 ; 1955 ; 4 dollars). For a very good reason the major part of this volume should be of absorbing interest for biologists in a number of different fields. It shows in a precise way, yet intelligible to those outside radiation biology, how varied are the methods now available which use ionizing radiations for analysing ultramicroscopic biological structures and their functions. This is more than can be said of the often ponderous other publications on radiation biology which have multiplied in recent years.

The essentials of the oldest and best-known radiation method are that localized releases of energy within a cell structure may cause it to lose or change one or more of its biological functions. Comparing loss of function caused by irradiation with different types and doses of radiation, one can infer something about the size, shape and molecular stability of the structures examined, and about the relations of these to function. This type of analysis has given useful results, for example, in the case of the structure and function of bacteriophage particles, of chromosomes and genes, and of various other cellular components. The same sort of analysis has been applied success. 